\title{
A study on the effect of different factors on profitability of banking system
}

\author{
Maryam Ghadimi $^{\mathbf{a}^{*}}$, Mehdi Taghavi ${ }^{\mathrm{b}}$ and Neda Kassaipour ${ }^{\mathrm{c}}$
}

${ }^{a}$ Department of Economic, University of Allame Tabatabaei, Tehran, Iran

${ }^{b}$ Professor and Faculty member, Department of Economic, University of Allame Tabatabaei, Tehran, Iran

${ }^{c}$ Department of Economic, Tarbiat Modares University (TMU), Tehran, Iran

\begin{tabular}{l}
\hline A R T I C L E I N F O \\
\hline Article history: \\
Received March 26, 2012 \\
Received in Revised form \\
June, 12, 2012 \\
Accepted 19 June 2012 \\
Available online \\
June 26 2012 \\
\hline Keywords: \\
Econometrics \\
Banking system \\
Profitability \\
Return on Asset
\end{tabular}

A B S T R A C T

\begin{abstract}
In this paper, we study the effect of different influencing factors on profitability of banking system in Iran for a panel data from 2001 to 2010. The sample of banking system includes ten different banks and two different types of internal and external variables are considered. Internal factors include ownership ratio, ratio of bank customers' deposit to banks' assets, ratio of total loans given to all assets, ratio of total interest free loans on total assets, ratio of interest free revenues on total revenue. External factors include economic growth, actual rate of interest and inflation rate. The proposed model of this paper uses econometrics method to investigate the proposed model and the preliminary results indicate that ownership ratio, ratio of total equity on total assets, along with inflation rate have negative impact on profitability. In addition, the ratio of customers' deposit on total assets, the ratio of total loans on total assets and economic growth have positive impact on profitability.
\end{abstract}

(C) 2012 Growing Science Ltd. All rights reserved.

\section{Introduction}

During the past few years, there have been tremendous efforts on measuring the impact of various factors on banking profitability. Kosmidou et al. (2006) discussed the relative importance of banking system in United kingdom and its impact on Euro zones' banking system, since over a quarter of all banking assets in the EU are kept in the UK and it is the biggest single international banking centre, accounting for $20 \%$ of the world's cross-border lending. The UK banking sector has been considered as one of the most open and it is characterized by a rapidly increasing foreign bank presence. Kosmidou et al. (2006) studied the performance of the banking sector in the UK concentrating on the performance of the domestic banks as opposed to the performance of the foreign banks operating in the UK. They used a multivariate analysis to determine the existing changes between the financial characteristics of domestic and foreign banks, considering profitability, liquidity, risk and efficiency factors.

* Corresponding author. Tel: +98-912-4599005

E-mail addresses: maryamghadimy@yahoo.com (M. Ghadimi) 
Ben Naceur and Kandil (2009) investigated the effect of capital requirements on banks' cost of intermediation and performance for a case of Egypt. The results indicated that bank-specific characteristics including bank capitalization and credit risk had a positive and significant influence on banks' net interest margin, cost efficiency, and profitability. Chen \& Liao (2011) studied the effect of governance and supervision on the performance of domestic and foreign banks. They found that foreign banks were more profitable than domestic banks when they operated in a host country whose banking sector was less competitive and when the parent bank in the home country was highly profitable.

Blum (1999) performed an investigation to find out whether capital adequacy requirements could reduce risks in banking or not and argued that any increase in capital could even increase risk taking behavior. We have seen such an unpleasant event during the year 2008 financial crises where a high risk policy from American banking industry created economic turmoil (Dietrich \& Wanzenried, 2011).

Williams (2003) proposed and examined a model, which integrated the existing multinational bank literature with the domestic bank profits literature. He gathered the necessary data from Australian banking system and showed that an integrated model results in a small increase in explanatory power when compared with models drawn solely from the multinational banking literature. He also reported that profits are a negative function of competitor market share and bank license status, and a positive function of Australian size and home GDP growth.

Barth et al. (2004) implemented a database on bank regulation (Beck et al., 2001) and supervision in 107 countries to evaluate the relationship between specific regulatory and supervisory practices and banking-sector, development and efficiency. The results of their investigation suggested that policies, which rely on guidelines that first of all force accurate information disclosure and secondly, empower private-sector corporate control of banks and finally foster incentives for private agents to exert

corporate control work best to encourage bank development, performance and stability. GarcíaHerrero et al. (2009) studied why Chineese banks do not report much profitability on their statements. They reported some negative impact for China's development banks, which are fully state-owned. Instead, more market-oriented banks, such as joint-stock commercial banks, were more profitable, which again points to the influence of government intervention in explaining bank performance in China.

\section{The proposed model}

The proposed model of this paper uses panel data to investigate the data based on the following regression function,

$$
Y_{i t}=\alpha_{i t}+\beta_{1} x_{1 i t}+\cdots+\beta_{k} x_{k i t}+u_{i t}, \quad u_{i}=\mu_{i}+v_{i t}
$$

where $u_{i}$ has a mean of zero, $\mu_{i}$ shows the effects of the differences in various components, $v_{i t}$ is also error term. We first examine the Heterogeneity effect using LIMMER F statistics. To do this test we use the following hypothesis

$$
\begin{aligned}
& H_{0}=\mu_{1}=\cdots=\mu_{n} \\
& H_{1}: \text { At least one of } \mu_{i} \neq 0 \\
& \text { F-statistic can be defined using the following, } \\
& F=\frac{(R R S S-U R S S) /(N-1)}{U R S S(N T-N-K)}
\end{aligned}
$$


where RRSS represents the sum of squares of restricted residuals, URSS is the sum of squares of unrestricted residuals and null hypothesis is rejected when calculated $\mathrm{F}$ value is greater than critical $\mathrm{F}$ value with degrees of freedom of (N-1) and (NT-N-K). Next we have to measure the effects of fixed and random effects using Hausman test, which is calculated as follows,

$$
W=\left(b_{S} \beta_{S}\right)^{\prime}\left(M_{1}-M_{0}\right)^{-1}\left(b_{S}-\beta_{S}\right) \approx \chi^{2 r},
$$

where $r$ is number of estimated parameters, $W$ maintains $\chi^{2}$ and its degree of freedom is equal to the number of parameters, $M_{1}$ is the matrix of variance/covariance for fixed effects' coefficient $\left(b_{s}\right)$ and $M_{0}$ is the matrix of variance/covariance for stochastic coefficients $\left(\beta_{s}\right)$. If $M_{0}$ and $M_{1}$ are linearly dependent then $b_{s}$ and $\beta_{s}$ are meaningfully different. According to Hausman test, the null hypothesis represents the selection of stochastic effect and alternative hypothesis represents the fixed effect.

\section{The results}

The proposed framework of the model we use in this paper considers the following regression model

$$
Y_{i t}=C+\sum \alpha_{i} A_{i j t}+\sum \beta_{i} X_{k t}+u_{i t} \text {, }
$$

where $C$ is the constant parameter, $\alpha_{i}$ and $\beta_{i}$ are model coefficients, $Y_{i t}$ is the dependent variable (i.e. return of assets (ROA)), $X_{k t}$ includes all independent variables and $A_{i j t}$ represents all macro economics figures such as actual rate of interest, economic growth and inflation rate.

\subsection{Sample size}

The sample size of this study includes all related data from different Iranian banks including Bank melli, Tejarat, Keshavarzi, Saderat, export developing bank of Iran, Maskan, Mine and Industry, Sepah and Refah. We have gathered time series data from 2000 to 2010. Since we considered the information of ten different banks for a period of eleven years, we have 110 observations.

\subsection{Data analysis}

In order to analyze the data we have use Evires 7 software package and as we explained we have used panel data method. Table 1 shows model estimation using fixed effect.

Table 1

\begin{tabular}{|c|c|c|c|c|}
\hline Variable & Coefficient & Std. Error & t-Statistic & Prob. \\
\hline $\mathrm{C}$ & 2.125012 & 0.097676 & 21.75578 & 0.0000 \\
\hline A1 & 2.480712 & 2.191007 & 4.129840 & 0.0401 \\
\hline A2 & -1.491211 & 1.301211 & -5.144296 & 0.0241 \\
\hline A3 & 6.481214 & 0.000799 & 3.008112 & 0.0535 \\
\hline $\mathrm{X} 1$ & -0.130192 & 0.110894 & -2.174080 & 0.0420 \\
\hline $\mathrm{X} 2$ & 0.025294 & 0.123566 & 3.984703 & 0.0380 \\
\hline $\mathrm{X} 3$ & 1.394291 & 0.086433 & 16.13138 & 0.0001 \\
\hline $\mathrm{X} 4$ & 0.001901 & 0.000806 & 2.357045 & 0.0595 \\
\hline $\mathrm{X} 5$ & 0.053508 & 0.115611 & 1.963312 & 0.0912 \\
\hline \multicolumn{5}{|c|}{ Effects Specification } \\
\hline \multicolumn{5}{|c|}{ Cross-section fixed (dummy variables) } \\
\hline R-squared & 0.812104 & & Mean dependent var & 1.169433 \\
\hline Adjusted R-squared & 0.709513 & & S.D. dependent var & 0.279981 \\
\hline S.E. of regression & 0.096375 & & Akaike info criterion & -1.751453 \\
\hline Sum squared resid & 1.513974 & & Schwarz criterion & -1.449896 \\
\hline Log likelihood & 174.6307 & & Hannan-Quinn criter. & -1.629184 \\
\hline F-statistic & 93.83192 & & Durbin-Watson stat & 1.801932 \\
\hline Prob(F-statistic) & 0.000000 & & & \\
\hline
\end{tabular}

$\underline{\text { Regression analysis based on fixed effect }}$ 
Table 2

Regression analysis based on random effect

\begin{tabular}{|c|c|c|c|c|}
\hline Variable & Coefficient & Std. Error & t-Statistic & Prob. \\
\hline $\mathrm{C}$ & 1.672853 & 0.133419 & 12.53830 & 0.0126 \\
\hline A1 & 1.731221 & 2.201211 & 5.781097 & 0.0359 \\
\hline A2 & -1.021217 & 1.301211 & -3.785295 & 0.0334 \\
\hline A3 & 0.000352 & 0.000803 & 3.978399 & 0.0617 \\
\hline $\mathrm{X} 1$ & -0.185085 & 0.117320 & -2.977604 & 0.0166 \\
\hline $\mathrm{X} 2$ & 0.035805 & 0.131551 & 2.272175 & 0.0058 \\
\hline X3 & 1.016493 & 0.118237 & 8.597072 & 0.0000 \\
\hline $\mathrm{X} 4$ & 0.044935 & 0.000869 & 3.736931 & 0.0617 \\
\hline $\mathrm{X} 5$ & 0.065454 & 0.073624 & 3.736931 & 0.0712 \\
\hline \multicolumn{3}{|c|}{$0.065454 \quad 0.073624$} & S.D. & Rho \\
\hline \multicolumn{3}{|c|}{ Cross-section random } & 0.036791 & 0.1272 \\
\hline \multicolumn{3}{|c|}{ Idiosyncratic random } & 0.096375 & 0.8728 \\
\hline \multicolumn{5}{|c|}{ Weighted Statistics } \\
\hline R-squared & 0.741211 & & & 0.614369 \\
\hline Adjusted R-squared & 0.883036 & & S.D. dependent var & 0.194138 \\
\hline S.E. of regression & 0.102170 & \multirow{3}{*}{\multicolumn{2}{|c|}{$\begin{array}{l}\text { Sum squared resid } \\
\text { Durbin-Watson stat }\end{array}$}} & 1.795443 \\
\hline F-statistic & 67.75614 & & & 1.761162 \\
\hline Prob(F-statistic) & 0.000000 & & & \\
\hline \multicolumn{5}{|c|}{ Unweighted Statistics } \\
\hline R-squared & 0.843617 & & Mean dependent var & 1.169433 \\
\hline Sum squared resid & 2.194328 & & Durbin-Watson stat & 0.868264 \\
\hline
\end{tabular}

Table 3

Model estimation using Pool technique Cross-section fixed (dummy variables)

\begin{tabular}{cccc}
\hline R-squared & 0.755526 & Mean dependent var & 1.169433 \\
Adjusted R-squared & 0.797316 & S.D. dependent var & 0.279981 \\
S.E. of regression & 0.070099 & Akaike info criterion & -2.237709 \\
Sum squared resid & 0.624054 & Schwarz criterion & -1.297561 \\
Log likelihood & 254.3938 & Hannan-Quinn criter. & -1.856520 \\
F-statistic & 80.47254 & Durbin-Watson stat & \\
\hline Prob(F-statistic) & 0.000000 & & 1.792010 \\
\hline
\end{tabular}

The results of Table 1, Table 2 and Table 3 indicate that we can reject the null hypothesis and conclude that the panel regression analysis can be used for the proposed study of this paper. We also used Hausman test to verify whether we should choose the fixed or stochastic method. Table 4 shows details of our findings.

Here, the null hypothesis is associated with selection of stochastic method and alternative hypothesis is associated with accepting fixed effects. Since the null hypothesis is accepted we can reject fixed effect and accept stochastic effects. Based on the results of Table 4, we can summarize the model as follows,

$$
\begin{gathered}
Y=1.67+1.73 A_{1 j}-1.02 A_{2 j}+0.0003 A_{3 j}-0.19 X_{1 k}+0.035 X_{2 k}+1.02 X_{3 k}+0.045 X_{4 k}+0.065 X_{5 k} \\
\text { (12.53) (5.78) (-3.79) (3.97) (-2.98) }
\end{gathered}
$$

In Eq. (5), $A_{1 j}$ represents economic growth, $A_{2 j}$ is inflation rate, $A_{3 j}$ is actual interest rate, respectively. In addition, $X_{1 k}$ is equity to assets ratio, $X_{2 k}$ is ratio from sum of loans given to customers on assets, $X_{3 k}$ is ratio of sum of banks' customers' deposits on sum of assets, $X_{4 k}$ is the ratio of total no interest costs on sum of assets and finally $X_{5 k}$ is portion of no interest income from total income, respectively. The numbers in parenthesis represent t-student values. As we can observe from the results, all t-student are meaningful when the level of significance is five percent. The 
goodness of fitness is $R^{2}=0.74$, which is fairly reliable value. F-statistic represents meaningful value, which validates the overall regression when the level of significance is set to five percent. A Durbin-Watson (DW) value of 1.76 indicates that there is no serial correlation between the residuals.

\section{Table 4}

The results of Hausman test

\begin{tabular}{|c|c|c|c|c|}
\hline Test Summary & & Chi-Sq. Statistic & Chi-Sq. d.f. & Prob. \\
\hline Cross-section random & & 0.000000 & 7 & 0.0272 \\
\hline \multicolumn{5}{|c|}{ Cross-section random effects test comparisons: } \\
\hline Variable & Fixed & Random & Var(Diff.) & Prob. \\
\hline A1 & -0.000000 & -0.000000 & 0.000000 & 0.0000 \\
\hline A2 & 0.000000 & 0.000000 & 0.000000 & 0.0000 \\
\hline A3 & 0.000352 & -0.000006 & 0.000000 & 0.0000 \\
\hline $\mathrm{X} 1$ & 0.185085 & 0.130199 & 0.001467 & 0.1518 \\
\hline $\mathrm{X} 2$ & 0.035805 & 0.025294 & 0.002037 & 0.8159 \\
\hline X3 & -1.016493 & -1.394291 & 0.006509 & 0.0000 \\
\hline $\mathrm{X} 4$ & 0.003248 & 0.001901 & 0.000000 & 0.0000 \\
\hline $\mathrm{X} 5$ & -0.000000 & -0.000000 & 0.000000 & 0.0000 \\
\hline
\end{tabular}

Cross-section random effects test equation:

Dependent Variable: Y

Method: Panel Least Squares

\begin{tabular}{|c|c|c|c|c|}
\hline Variable & Coefficient & Std. Error & t-Statistic & Prob. \\
\hline $\mathrm{C}$ & 1.672853 & 0.133419 & 12.53830 & 0.0126 \\
\hline A1 & 1.731221 & 2.201211 & 5.781097 & 0.0359 \\
\hline A2 & -1.021217 & 1.301211 & -3.785295 & 0.0334 \\
\hline A3 & 0.000352 & 0.000803 & 3.978399 & 0.0617 \\
\hline $\mathrm{X} 1$ & -0.185085 & 0.117320 & -2.977604 & 0.0166 \\
\hline $\mathrm{X} 2$ & 0.035805 & 0.131551 & 2.272175 & 0.0058 \\
\hline X3 & 1.016493 & 0.118237 & 8.597072 & 0.0000 \\
\hline $\mathrm{X} 4$ & 0.044935 & 0.000869 & 3.736931 & 0.0617 \\
\hline $\mathrm{X} 5$ & 0.065454 & 0.073624 & 3.736931 & 0.0712 \\
\hline \multicolumn{5}{|c|}{ Effects Specification } \\
\hline \multicolumn{5}{|c|}{ Cross-section fixed (dummy variables) } \\
\hline R-squared & 0.741211 & Mean dep & & 0.614369 \\
\hline Adjusted R-squared & 0.883036 & S.D. depe & & 0.194138 \\
\hline S.E. of regression & 0.102170 & Akaike in & & 1.795440 \\
\hline Sum squared resid & 1.513974 & Schwarz & & -1.449896 \\
\hline Log likelihood & 174.6307 & Hannan-Q & & -1.629184 \\
\hline F-statistic & 67.75614 & Durbin-W & & 1.761620 \\
\hline Prob(F-statistic) & 0.000000 & & & \\
\hline
\end{tabular}

Based on the results we understand that the ratio of equity to assets, and the ratio from sum of loans given to customers on assets have opposite effects. In other words, an increase of one unit in this ratio will reduce profitability by 0.19 and an increase of unit in total loans will increase profitability by 0.035. The ratio of sum of banks' customers' deposits on sum of assets is 1.02. This means an increase of one percent on this ratio, profitability will increase too. The same holds for two other ratios of no interest costs on sum of assets and no interest income from total income. Inflation has strong negative impact on profitability and an increase of one percent on inflation rate will reduce profitability by .102 percent. When the economy grows, we can expect the profitability to grow faster and this is what we see from the results since one percent increase in economic growth will increase profitability by 1.73 percent.

\section{Conclusion}

In this paper, we have performed an empirical investigation to detect different influencing factors on Iranian banking profitability. The investigation was performed on 11 active banks using the financial information from year 2000 to year 2010. The results have disclosed that the effect of equity to assets ratio has a negative impact on banks' profitability. This means that management teams of these banks could adjust the ownership ratio so well to have positive impact on their banking profitability. In other words, an increase on ownership ratio was not only specified on assets and it was consumed in other assets as well. The ratio of loans on total assets directly impacted profitability, significantly. There 
was a positive relationship between total deposits to total assets ratio and return on assets. Since the main responsibility of banks is to give loan to their customers and this will not happen unless people deposit savings with banks, the results of our survey indicate that people are interested in keeping their money with banks. The other observation was that the increase on inflation substantially hurts banking profitability and the reason for this is because in the event of inflation people withdraw their deposits from banks and invest them in other assets such as real state or exchange their money to other currencies, etc. Finally, when the economy has a positive trend on upcoming market, banking systems in Iran seem to enter into booming stage.

\section{References}

Barth, J., Caprio, G. \& Levine, R. (2004). Bank regulation and supervision: What works best. Journal of Financial Intermedition, 13, 205-248

Beck, T., Demirgüç-Kunt, A., \& Levine, R. (2001). The financial structure database. In: DemirgüçKunt, A., Levine, R. (Eds.), Financial Structure and Economic Growth: A Cross-Country Comparison of Banks, Markets, and Development. MIT Press, Cambridge, MA, pp. 17-80.

Ben Naceur, S., \& Kandil, M. (2009). The impact of capital requirements on banks' cost of intermediation and performance: The case of Egypt. Journal of Economics and Business, 61(1), 70-89.

Blum, J. (1999). Do capital adequacy requirements reduce risks in banking? Journal of Banking Finance, 23, 755-771.

Chen, S.H., \& Liao, C.C. (2011). Are foreign banks more profitable than domestic banks? Home- and host-country effects of banking market structure, governance, and supervision. Journal of Banking \& Finance, 35(4), 819-839.

Dietrich, A., \& Wanzenried, G. (2011). Determinants of bank profitability before and during the crisis: Evidence from Switzerland. Journal of International Financial Markets, Institutions and Money, 21(3), 307-327.

García-Herrero, A., Gavilá, S., \& Santabárbara, D. (2009). What explains the low profitability of Chinese banks?. Journal of Banking \& Finance, 33(11), 2080-2092.

Kosmidou, K., Pasiouras, F., Doumpos, M., \& Zopounidis, C. (2006). A Multivariate analysis of the financial characteristics of foreign and domestic banks in the UK. Omega, 34(2), 189-195.

Williams, B. (2003). Domestic and international determinants of bank profits: foreign bank in Australia. Journal of Banking and Finance, 27(6), 1185-1210. 